DOI: https://doi.org/10.12962/j26139960.v6i1.144 $\quad$ Naskah Masuk 18-11-2021; $\quad$ Naskah Diulas 07-12-2021; $\quad$ Naskah Diterima 23-12-2021

\title{
Klinik Penyusunan Rencana Program Pembelajaran (RPP) dan Pelatihan TIK bagi Guru Pos PAUD Terpadu (PPT) Mawar di Surabaya
}

\author{
Victor Hariadi $^{1, *}$ | Joko Lianto Buliali ${ }^{1}$ | Ahmad Saikhu ${ }^{1}$ | Yudhi Purwananto ${ }^{1}$ | Bilqis \\ Amaliah $^{1}$ | Arya Yudi Wijaya ${ }^{1}$
}

\footnotetext{
${ }^{1}$ Departemen Teknik Informatika, Institut Teknologi Sepuluh Nopember, Surabaya, Indonesia
}

\section{Korespondensi}

*Victor Hariadi, Departemen Teknik Informatika, Institut Teknologi Sepuluh Nopember, Surabaya, Indonesia. Alamat e-mail: victorhariadi1228@gmail.com

\footnotetext{
Alamat

Laboratorium Pemodelan dan Komputasi, Departemen Teknik Informatika, Institut Teknologi Sepuluh Nopember, Surabaya, Indonesia
}

\begin{abstract}
Abstrak
Pendidikan Anak Usia Dini (PAUD) merupakan pondasi awal bagi pertumbuhan dan perkembangan selanjutnya. Ontologis anak sebagai makhluk mempunyai aspek biologis dan psikologis. Pembelajaran pada anak usia dini haruslah menggunakan konsep belajar melalui bermain, belajar sambil berbuat, serta melalui stimulasi PAUD berdasarkan aspek pedagogis. Dari segi empiris PAUD sangat penting, antara lain menjelaskan bahwa pada waktu manusia lahir, kelengkapan organisasi otak memuat 100-200 milyar sel otak yang siap dikembangkan serta diaktualisasikan mencapai tertinggi. Selain itu tujuan PAUD yang ingin dicapai adalah mengembangkan pengetahuan dan pemahaman orang tua dan guru serta pihak-pihak yang terkait dengan pendidikan dan perkembangan anak usia dini. Oleh karenanya sangat penting bagi guru-guru PAUD untuk senantiasa mengevaluasi dan memperbaharui kurikulum dan metode pengajaran kepada anak-anak usia dini ini. Selain melalui pemahaman dan pengaplikasian penduan yang dibuat oleh dinas pendidikan setempat, juga yang tidak pentingnya adalah berdiskusi dan memahami perkembangan teknologi informasi terkini, baik dijadikan sebagai sisipan bahan ajar, maupun sebagai perangkat bantu pengajaran. Dalam pelaksanaan kegiatan pengabdian kepada masyarakat ini akan dilaksanakan diskusi penyusunan Rencana Program Pembelajaran (RPP) serta pelatihan Teknologi Informasi dan Komunikasi (TIK) yang dapat dimanfaatkan sebagai media pembelajaran kepada anak-anak usia dini. Diharapkan melalui kegiatan ini guru-guru PAUD dapat mengikuti perkembangan teknologi terkini serta dapat meningkatkan kualitas pembelajaran kepada siswa-siswa PAUD yang diasuhnya.
\end{abstract}

\section{Kata Kunci:}

PAUD, RPP, Perangkat Bantu Pengajaran, Pelatihan TIK, Klinik. 


\section{1 | PENDAHULUAN}

Pendidikan anak usia dini merupakan salah satu bentuk penyelenggaraan pendidikan yang menitikberatkan pada peletakan dasar ke arah pertumbuhan dan perkembangan fisik (koordinasi motorik halus dan kasar), kecerdasan (daya pikir, daya cipta kecerdasan emosi, kecerdasan spiritual), sosio emosional (sikap dan perilaku serta beragama), bahasa dan komunikasi, sesuai dengan keunikan dan tahap-tahap perkembangan yang dilakukan oleh anak usia dini. Tujuan pendidikan memiliki dua fungsi yaitu memberikan arah kepada segenap kegiatan pendidikan dan merupakan sesuatu yang ingin dicapai oleh segenap kegiatan pendidikan. Pendidikan Anak Usia Dini (PAUD) merupakan upaya pendidikan anak usia dini lahir hingga delapan tahun, berfungsi mengembangkan potensi anak dan membentuk kepribadian anak dengan benar ${ }^{[1]}$. Beberapa tujuan PAUD, antara lain: (1) membentuk anak Indonesia yang berkualitas; (2) membantu menyiapkan anak mencapai kesiapan belajar di sekolah; (3) intervensi dini dengan memberikan rangsangan sehingga dapat menumbuhkan potensi-potensi yang tersembunyi; (4) dan melakukan deteksi dini terhadap kemngkinan terjadinya gangguan terhadap pertumbuhan dan perkembangan anak.

Secara umum, tujuan PAUD untuk mengembangkan berbagai potensi anak sejak dini sebagai persiapan untuk hidup dan dapat menyesuaikan diri dengan lingkungannya. PAUD membantu perkembangan motorik, kognitif, bahasa, dan sosial emosi. Pendidikan nasional berfungsi untuk mencerdaskan setiap bangsanya, mengembangkan setiap potensi yang dimiliki oleh peserta didik. PAUD memiliki fungsi untuk mengembangkan seluruh potensi anak didiknya dengan benar secara jasmani dan rohani, pembentukan karakter anak (menanamkan kedisplinan pada anak, bersosialisasi dengan sesama teman maupun pada guru), memberikan kesempatan anak untuk bermain sekaligus belajar. PAUD dipengaruhi oleh 3 lingkungan pendidikan utama yakni keluarga, sekolah, dan masyarakat dan ketiga lingkungan tersebut dinamakan tripusat ${ }^{11}$.

Pendidikan anak merupakan tanggungjawab bersama antara orang tua dan sekolah. Orang tua tidak dapat sepenuhnya membebankan proses pendidikan anaknya pada sekolah. Idealnya proses pendidikan yang berlangsung di satuan pendidikan dapat menghasilkan peserta didik yang tidak hanya memiliki kompetensi secara intelektual namun hendaknya juga memiliki akhlak mulia. Dengan bekal ahklak mulia ini peserta didik akan berkembang menjadi anak yang baik dan akan menjadi dewasa kelak memiliki karakter yang kuat bermanfaat bagi nusa dan bangsa Pembudayaan karakter adalah kegiatan yang harus dilakukan oleh peserta didik, guru, tenaga kependidikan dan orang tua/wali untuk menumbuhkan kebiasaan yang baik dan membentuk generasi berkarakter Pancasila dengan mengembangkan potensi peserta didik agar menjadi manusia berhati, berpikir baik, dan berperilaku baik dan membangun bangsa yang berkarakter Pancasila. Untuk memperkuat pelaksanaan pendidikan karakter pada sekolah yang bersumber dari agama, Pancasila, budaya dan tujuan pendidikan nasional, meliputi: regilius, jujur, toleransi, disiplin, kerja keras, kreatif, mandiri, demokratis, rasa ingin tahu, semangat kebangsaan, cinta tanah air, bersahabat/komunikatif, cinta damai, peduli lingkungan, peduli sosial dan tanggungjawab.

Pembudayaan sikap dan perilaku di sekolah dapat dilakukan melalui program yang dibuat oleh Satuan PAUD untuk mendesain skenario pembiasaan pembudayaan karakter, sebagai contoh guru mengintegrasikan sikap dan perilaku baik sebelum pembelajaran, pada saat pembelajaran, dan istirahat/bermain, atau guru ekstrakurikuler (drumband, menari, melukis) dapat membantu pembiasaan sikap dan perilaku baik melalui; disiplin dalam menggunakan peralatan drumband, dalam gerakan tari yang memiliki nilai nilai budi pekerti, melukis dengan mengaitkan ajaran agama. Lingkungan keluarga memiliki program untuk pendidikan anak, seperti perbaikan gizi, permaian edukatif, pengembangan nilai moral, nilai budaya, keyakinan agama, hal ini dikembangkan selanjutnya di sekolah dan masyarakat. Lingkungan sekolah mengupayakan program-program yang lebih mendekatkan sekolah dengan orang tua peserta didik (organisasi orang tua, kunjungan rumah oleh pihak sekolah, dan sebagainya), selanjutnya sekolah juga mengupayakan program yang berkaitan erat dengan masyarakat di sekitarnya ${ }^{[2]}$.

Kontribusi tripusat pendidikan yang saling memperkuat dan saling melengkapi itu akan memberi peluang mewujudkan sumber daya manusia terdidik daya manusia terdidik yang bermutu. Adapun hal yang dapat dilaksanakan dalam Pembudayaan Karakter PAUD, adalah ${ }^{11}$ :

1. Berbaris setiap akan masuk kelas, berdoa sebelum kegiatan belajar mengajar, memberi salam, senyum dan sapaan kepada setiap orang di sekolah;

2. Membersihkan lingkungan sekolah, mencuci tangan, menerima sesuatu selalu dengan tangan kanan;

3. Tidak berkata-kata kotor kasar dan sombong, tidak meludah di sembarang tempat; 
4. Menghormati orang yang lebih tua, menekankan nilai regilius (beragama Islam membaca/menghapalkan Iqro/surat pendek);

5. Ekstrakurikuler (drumband, menari, melukis).

Diharapkan di lingkungan sekolah, guru dapat mengawasi sekaligus membantu anak untuk menemukan potensi mereka dan dikembangkan dengan baik, sesuai dengan potensi yang dimiliki anak.Tapi bukan hanya di lingkungan sekolah saja anak harus mendapatkan pendidikan, dari lingkungan keluarga maupun lingkungan masyarakat. Supaya ketika anak sudah menginjak usiasekolah dasar, anak mampu mempersiapkan diri untuk pendidikan selanjutnya. Peranan keluarga, sekolah dan masyarakat sebagai lingkungan pendidikan sebagai tripusat pendidikan sangat dibutuhkan untuk kelancaran proses pendidikan anak. Perkembangan kognitif yang akan dibahas meliputi: perkembangan cara berpikir, persepsi, memori, atensi, bahasa, dan emosi. Kognitif dapat berarti kecerdasan, berfikir, dan mengamati, yaitu tingkah laku yang mengakibatkan orang memperoleh pengetahuan atau yang diperlukan untuk menggunakan pengetahuan. Dengan pengertian ini, maka anak yang mampu mengkoordinasikan pelbagai cara berfikir untuk menyelesaikan persoalan-persoalan dengan merancang, mengingat, dan mencari alternatif bentuk penyelesaian persoalan, merupakan tolok ukur perkembangan kognitif. Apabila mengamati cara berfikir dan tingkah laku anak usia prasekolah, maka cara berfikir mereka termasuk semi logis, yaitu setengah masuk akal. Pada tahap cara berpikir anak masih berpusat pada apa yang dipersepsikan sendiri, tidak melihat dari sisi yang dipersepsikan oleh orang lain ${ }^{\sqrt{3}}$.

Anak usia dini dalam memandang suatu keadaan lebih memfokuskan pada tampilan keadaan, bukan pada isi atau kenyataan di balik tampilan itu. Anak pendidikan anak usia dini berfikir hanya pada keadaan "sebelum" dan "sesudah", tidak pada proses perubahan dari sebelum dan sesudah melihat tampilan suatu keadaan. Kekakuan berfikir ini karena mereka tidak dapat berfikir dari sisi kebalikannya suatu rangkaian kejadian atau perubahan bentuk. Perkembangan persepsi anak usia dini terhadap objek semakin baik seiring dengan peningkatan ketajaman visualnya. Kemampuan memori tergantung kepada pengulangan informasi. Pengulangan informasi itu penting. Kecepatan dan efisiensi pemrosesan informasi juga penting, terutama item-item ingatan yang dapat diidentifikasi. Kecepatan pengulangan informasi merupakan estimasi akurat bagi rentang memori, apalagi jika kecepatan pengulangan itu terstandar, maka rentang memori jangka pendek anak usia dini sama dengan memori orang dewasa muda 3 .

Perkembangan memori jangka panjang anak prasekolah umumnya memiliki kemampuan pengenalan (recognition) yang lebih baik, tetapi kemampuan pemanggilan kembali agak kurang. Untuk mengukur kedua aspek memori jangka panjang tersebut, pada umumnya yang dilakukan adalah mengukur recall daripada mengukur recognition, sebab recall membutuhkan strategi pengulangan yang aktif dan berlangsung terus menerus dalam memori. Perkembangan atensi anak prasekolah biasanya lebih tertuju kepada hal-hal yang menarik dan lucu, yang kemudian tersimpan lebih lama dalam memorinya. Misalnya pertunjukan badut yang lucu. Atensi adalah respon dalam sistem kognitif yang terkonsentrasi pada satu objek atau suatu tugas mental, di mana anak meniadakan stimulus lain yang mengganggu. Atensi juga dapat diartikan mengabaikan semua pesan, kecuali pesan tertentu yang biasanya lebih menarik. Hilangnya atensi dan pulihnya atensi berkaitan dengan kecerdasan anak. Perkembangan bahasa anak prasekolah seiring dengan perkembangan kognitifnya ${ }^{[3}$.

Kemampuan anak usia dini memahami bahasa orang lain masih terbatas. Anak pra sekolah hanya memahami bahasa dari persepsi dirinya sendiri dan akselerasi perkembangan bahasa anak terjadi sebagai hasil perkembangan fungsi simbolis. Apabila fungsi simbolis telah berkembang, akan memperluas kemampuan memecahkan persoalan dengan belajar dari bahasa orang lain. Bahasa merupakan bentuk utama dalam mengekspresikan pikiran dan pengetahuan jika anak mengadakan hubungan dengan orang lain. Anak yang sedang tumbuh kembang mengkomunikasikan kebutuhan, pikiran, dan perasaan melalui bahasa dengan kata-kata yang mempunyai makna. Berbahasa menghasilkan bunyi verbal. Kemampuan mendengar dan membuat bunyi verbal merupakan hal utama untuk menghasilkan pembicaraan. Kemampuan berbicara anak meningkat melalui pengucapan suku kata yang berbeda-beda yang diucapkan anak secara jelas. Kemampuan berbicara akan lebih baik bila anak memberi arti katakata baru, menggabungkan kata-kata baru, memberikan pernyataan atau pertanyaan. Semua ini merupakan gabungan proses berbicara, kreativitas, dan berfikir. Berfikir adalah awal berbahasa, dan berfikir lebih luas dari bahasa ${ }^{[1]}$.

Beberapa metode pembelajaran yang dianggap sesuai untuk PAUD, di antaranya adalah sebagai berikut. Bercerita, adalah cara bertutur dan menyampaikan cerita secara lisan. Cerita harus diberikan secara menarik. Anak diberi kesempatan untuk bertanya dan memberikan tanggapan. Pendidik dapat menggunakan buku sebagai alat bantu bercerita. Demonstrasi, digunakan untuk menunjukkan atau memeragakan cara untuk membuat atau melakukan sesuatu. Bercakap-cakap, dapat dilakukan dalam bentuk tanya jawab antara anak dengan pendidik atau antara anak dengan anak yang lain. Pemberian tugas, dilakukan oleh pendidik untuk memberi pengalaman yang nyata kepada anak baik secara individu maupun secara berkelompok. Sosio-drama/bermain 
peran, dilakukan untuk mengembangkan daya khayal/imajinasi, kemampuan berekspresi, dan kreativitas anak yang diinspirasi dari tokoh-tokoh atau benda-benda yang ada dalam cerita ${ }^{4}$. Karyawisata, adalah kunjungan secara langsung ke objek-objek di lingkungan kehidupan anak yang sesuai dengan tema yang sedang dibahas. Proyek, merupakan suatu tugas yang terdiri atas rangkaian kegiatan yang diberikan oleh pendidik kepada anak, baik secara individu maupun secara berkelompok dengan menggunakan objek alam sekitar maupun kegiatan sehari-hari. Eksperimen, merupakan pemberian pengalaman nyata kepada anak dengan melakukan percobaan secara langsung dan mengamati hasilnya.

Pengembangan kurikulum itu harus didasarkan oleh prinsip-prinsip perkembangan anak. Tujuan kurikulum itu sendiri untuk membantu kegiatan belajar anak yang dalam kegiatan tersebut kurikulum dapat memberikan arah yang tepat dan hasil yang ingin dicapai. Lingkungan pendidikan yang utama ialah keluarga dan peran orang tua dalam hal pendidikan anak sangatlah penting, karena sejak lahir anak secara tidak langsung mendapatkan pendidikan dari orang tua, melatih dan memberi anak petunjuk tentang berbagai aspek kehidupan, hingga anak menjadi dewasa dan mandiri. Keluarga merupakan tempat pendidikan yang sempurna. Lingkungan keluarga memberikan keterampilan, nilai moral, nilai budaya, bersosialisasi, keyakinan agama, adab pergaulan, sehingga anak dapat tubuh dan berkembang dengan baik. Lingkungan keluarga merupakan pusat pendidikan yang penting dan menentukan, karena itu tugas pendidikan adalah mencari cara, dan membantu ibu untuk mendidik anaknya secara optimal.

Oleh karenanya proses penyusunan dokumen Rencana Program Pembelajaran (RPP) menjadi hal yang sangat penting. Selain mengacu kepada pedoman/panduan yang dikeluarkan oleh Dinas Pendidikan Kota Surabaya, juga guru-guru PAUD harus mampu memberikan/ menambahkan muatan materi yang sesuai dengan karakteristik PAUD-nya masing-masing.

\section{2 | KONSEP DAN STRATEGI KEGIATAN}

Pada subbab sebelumnya telah diuraikan mengenai apa dan bagaimana PAUD yang ada di Indonesia. Selanjutnya gambaran mengenai situasi dan kondisi PAUD Mawar yang ada di Surabaya adalah saat ini PAUD Mawar memiliki 9 orang guru, dengan distribusi ke dalam 3 kelas berdasarkan usia peserta didik. Kelas A untuk rentang usia 2-3 tahun, diajar oleh 3 orang guru. Kelas B untuk rentang usia 3-4 tahun diajar oleh 3 orang guru. Dan kelas C untuk usia 4-5 tahun diajar oleh 3 orang guru. Guru-guru PAUD Mawar ini tidak semua berlatar pendidikan sarjana. Karena ditilik dari sejarah berdirinya PAUD Mawar ini didirikan oleh ibu-ibu PKK perumahan Rungkut Barata Surabaya pada tahun 2007. Dan dalam setiap tahun ajaran jumlah peserta didik pada PAUD Mawar ini berjumlah antara 20-40 siswa(i).

Sehingga yang menjadi konsep kegiatan pengabdian masyarakat ini berupa penyusunan dan implementasi program pemberdayaan masyarakat terutama untuk meningkatkan kemampuan masyarakat dalam pengembangan usaha dan pengembangan organisasi pada kelompok guru-guru PAUD, berupa peningkatan pengetahuan dan ketrampilan teknis untuk meningkatkan kompetensi guru di dalam bidang TIK dan penyusunan Rencana Program Pembelajaran (RPP). Ini merupakan bagian dari sustainable development goals, karena RPP yang baik akan mendasari pelaksanaan proses belajar-mengajar yang berkualitas, disamping pentingnya kualitas guru dalam menyampaikan materinya.

Dengan konsep kegiatan berupa peningkatan ketrampilan teknis bagi PAUD, dan dengan kemampuan pelaksana kegiatan dari perguruan tinggi yang berlatar belakang dosen teknik informatika, maka strategi kegiatan yang harus dilakukan antara lain yaitu, diskusi dengan para guru tersebut untuk memahami pedoman dan panduan yang dikeluarkan oleh Dinas Pendidikan Kota Surabaya dan menjaring masukan dari para guru mengenai konten lokasi yang hendak disisipkan dalamn RPP tersebut. Untuk kemudian bersama menyusun tabel RPP menggunakan software komputer.

\section{3 | METODE PELAKSANAAN KEGIATAN}

Pelaksanaan kegiatan "Klinik Penyusunan Rencana Program Pembelajaran (RPP) dan Pelatihan TIK bagi Guru Pos PAUD Terpadu (PPT) Mawar di Surabaya" ini akan dilakukan dengan beberapa pendekatan spesifik yang bertujuan untuk menjamin kesesuaian antara kebutuhan dengan solusi yang akan ditawarkan. Strategi pendekatan tersebut antara lain adalah:

- Pemilihan lingkup/skala mitra kegiatan

Kegiatan pengabdian ini dirancang untuk diaplikasikan kepada kelompok masyarakat yang berada di sekitar kampus ITS 
Sukolilo Surabaya. Dimana kelompok masyarakat tersebut dapat dibantu melalui keahlian yang dimiliki oleh para pelaksana kegiatan pengabdian masyarakat, yakni dalam bidang pendidikan. Lokasi/domisili mitra kegiatan menjadi pertimbangan penting, dimana diprioritaskan usaha atau lembaga yang berada sedekat mungkin dengan lokasi kampus ITS. Selain karena tanggung jawab moral bagi akademisi ITS untuk membantu kelompok masyarakat yang keberadaannya dekat dengan kampus ITS, juga pertimbangan masalah efisiensi waktu dan biaya.

- Kesesuaian antara bidang kompetensi dengan permasalahan yang ada

Diperlukan penjajagan awal (survey pendahuluan) untuk menentukan cluster usaha/lembaga yang dapat/sesuai dibantu dengan pertimbangan kemampuan teknis yang dimiliki oleh pelaksana kegiatan dapat menyelesaikan permasalahan yang ada, yaitu di bidang teknologi informasi.

- Ketersediaan Biaya

Dengan ketersediaan biaya yang tidak besar maka diperlukan upaya-upaya untuk merancang solusi dengan konsep "teknologi tepat guna" atau pelatihan terstruktur agar mudah dan murah dalam pengimplementasian/pelaksanaannya serta lebih terjamin kesinambungannya di kemudian hari.

Sementara rangkaian rencana kegiatan yang akan dilakukan di dalam melaksanakan kegiatan pengabdian kepada masyarakat ini antara lain:

1. Melakukan survey dan serangkaian diskusi untuk menginventarisasi, menentukan lingkup dan menyepakati permasalahan-permasalahan yang akan diselesaikan. Mendiskusikan metodologi pelaksanaan kegiatan serta menyepakati alokasi-alokasi waktu pelaksanaannya;

2. Melakukan serangkaian diskusi lanjutan untuk menyepakati jenis pelatihan TIK yang secara prioritas sangat dibutuhkan untuk saat ini;

3. Melakukan penyusunan buku panduan pelatihan;

4. Melakukan rangkaian pelatihan secara bertahap;

5. Melakukan publikasi kegiatan;

6. Menyusun laporan kegiatan sebagai bentuk pertanggung jawaban pelaksana kegiatan.

Kegiatan pengabdian kepada masyarakat ini sebagai salah bentuk pengabdian yang dapat dilakukan oleh akademisi kepada masyarakat. Dan dengan harapan bahwa kegiatan ini dapat terlaksana dengan baik, sehingga kegiatan semacam ini dapat memberikan manfaat yang positif bagi kedua belah pihak. Dimana bagi masyarakat, keberadaan ITS sebagai institusi pendidikan tinggi negeri terkemuka di Indonesia dapat secara nyata membantu menyelesaikan permasalahan-permasalahan teknis yang ada di masyarakat. Sedangkan bagi akademisi, kegiatan pengabdian kepada masyarakat ini dapat menjadi pemacu untuk semakin menggali ide-ide kreatif mengenai pemanfaatan teknologi tepat guna yang sesuai bagi masyarakat di sekitarnya.

Selain itu terdapat pula manfaat positif yang dapat diperoleh mahasiswa-mahasiswa yang terlibat dalam kegiatan-kegiatan semacam ini, yaitu menambah wawasan mengenai aplikasi dari ilmu pengetahuan yang diperoleh di bangku kuliah, memberikan pengalaman bekerja di lapangan di bawah arahan dosen, dan memberikan ide/inspirasi bagi kegiatan kewirausahaan yang mungkin dapat dilakukan oleh para mahasiswa ini.

Dari begitu banyak manfaat positif yang terkandung di dalam kegiatan pengabdian kepada masyarakat semacam ini maka diharapkan akan muncul ide-ide dan pemikiran-pemikiran baru untuk keberlanjutan kegiatan ini, seperti misalnya:

- Keberhasilan sebuah aplikasi dengan pola link-and-match oleh perguruan tinggi pada sebuah cluster usaha-usaha mikrokecil atau organisasi/lembaga nirlaba dan pendidikan usia dini dapat diterapkan kepada cluster-cluster lain (dengan sedikit customized atau penyesuaian);

- Mendekatkan mahasiswa dengan lembaga-lembaga nirlaba atau kelompok masyarakat di sekitarnya yang memerlukan bantuan berupa sharing pengetahuan dan keahlian sehingga dapat mengasah kepekaan mahasiswa kepada kebutuhan masyarakat sekitarnya. Selain itu diharapkan dapat memunculkan ide dan minat untuk berkreatifitas melalui program-program kreatifitas 
mahasiswa yang sedang digalakkan oleh pemerintah. Terdapat 5 (lima) orang mahasiswa yang mengikuti program kegiatan pengabdian kepada masyarakat ini, yaitu:

1. Muhammad Wildan Kamal Al Hakim (5025211201 / Departemen Teknik Informatika ITS)

2. Muhammad Faiz Fernanda (5025211186 / Departemen Teknik Informatika ITS)

3. Hana Maheswari (5025211182 / Departemen Teknik Informatika ITS)

4. Sandyatama Fransisna Nugraha (5025211196 / Departemen Teknik Informatika ITS)

5. Dawamul Fikri Aqil (5025201025 / Departemen Teknik Informatika ITS)

\section{4 | TARGET DAN LUARAN KEGIATAN}

Agar tingkat keberhasilan kegiatan pengabdian kepada masyarakat berupa "Klinik Penyusunan Rencana Program Pembelajaran (RPP) dan Pelatihan TIK bagi Guru Pos PAUD Terpadu (PPT) Mawar di Surabaya" ini dapat terukur keberhasilannya maka terdapat beberapa hal yang dapat ditargetkan menjadi luaran dari kegiatan ini, yaitu antara lain:

- Tersusunnya modul panduan untuk pelatihan Penyusunan Rencana Program Pembelajaran (RPP) dan Pelatihan TIK;

- Terlaksananya pelatihan TIK bagi guru-guru PAUD Mawar Surabaya;

- Terpublikasinya kegiatan abdimas ini pada jurnal abdimas Sewagati tahun 2021.

Kegiatan abdimas yang telah dijalankan selama kurang lebih 8 (delapan) bulan ini telah terlaksana dengan baik sesuai rencana semula. Meski di beberapa bulan awal pelaksanaan masih terkendala dengan situasi pandemi akibat covid-19, namun seiring dengan semakin besarnya jumlah masyarakat yang telah tervaksinasi dan menurunnya level PPKM di kota Surabaya, maka pelatihan secara luring dapat dilaksanakan dengan baik. Tentu dengan tetap menerapkan prosedur kesehatan yang ketat, seperti peserta yang diperkenankan mengikuti pelatihan adalah yang telah menerima vaksin lengkap, pemeriksaan suhu badan sebelum memasuki ruangan pelatihan, penyediaan hand sinitizer di area pelatihan, serta diharuskan tetap mengenakan masker selama pelatihan berlangsung. Pelaksanaan pelatihan secara luring dengan tetap menerapkan protokol kesehatan dapat dilihat pada foto-foto berikut:

\section{5 | KEBERLANJUTAN}

Inti dari pelaksanaan kegiatan pengabdian abdimas kali ini adalah berdiskusi dan bertukar pikiran serta pengalaman antara guru-guru PAUD dengan akademisi ITS Surabaya mengenai teknik penyusunan RPP (Rencana Program Pembelajaran). Dimana kedua belah pihak yang berkecimpung dalam dunia pendidikan memiliki tugas dan tanggung jawab yang hampir sama.

Penyusunan dokumen RPP bagi guru-guru PAUD dilakukan melalui pemahaman terhadap dokumen kurikulum baku yang dikeluarkan oleh Kementrian Pendidikan dan Kebudayaan dan dinas-dinas terkait (Dinas Pendidikan Provinsi dan Kotamadya/Kabupaten). Jadi ada garis besar materi (nasional dan daerah) yang harus diakomodasi oleh guru-guru PAUD, sebelum sisanya dapat disisipi dengan materi kekhususan yang mencerminkan karakteristik masing-masing PAUD.

Sebagai keberlanjutan dari kegiatan yang telah selesai dilakukan adalah guru-guru PAUD ini dapat mengembangkan dokumen RPP dengan pendekatan-pendekatan sesuai dengan hasil diskusi dengan para akademisi. Termasuk di dalamnya dapat menyisipkan materi lokal sesuai dengan masukan yang diberikan selama pelatihan berlangsung. Seperti misalnya mengenalkan tentang robotika kepada anak-anak didik PAUD. Selain karena tidak terlalu sulit bagi anak-anak, robotika juga akan selalu menarik bagi anak-anak. Pelajaran robotika memiliki sisi positif bagi anak-anak terutama dalam hal melatih kreativitas, inovasi serta dapat melatih anak-anak untuk berpikir sistematis, karena memiliki unsur pelajaran programming di dalamnya. 


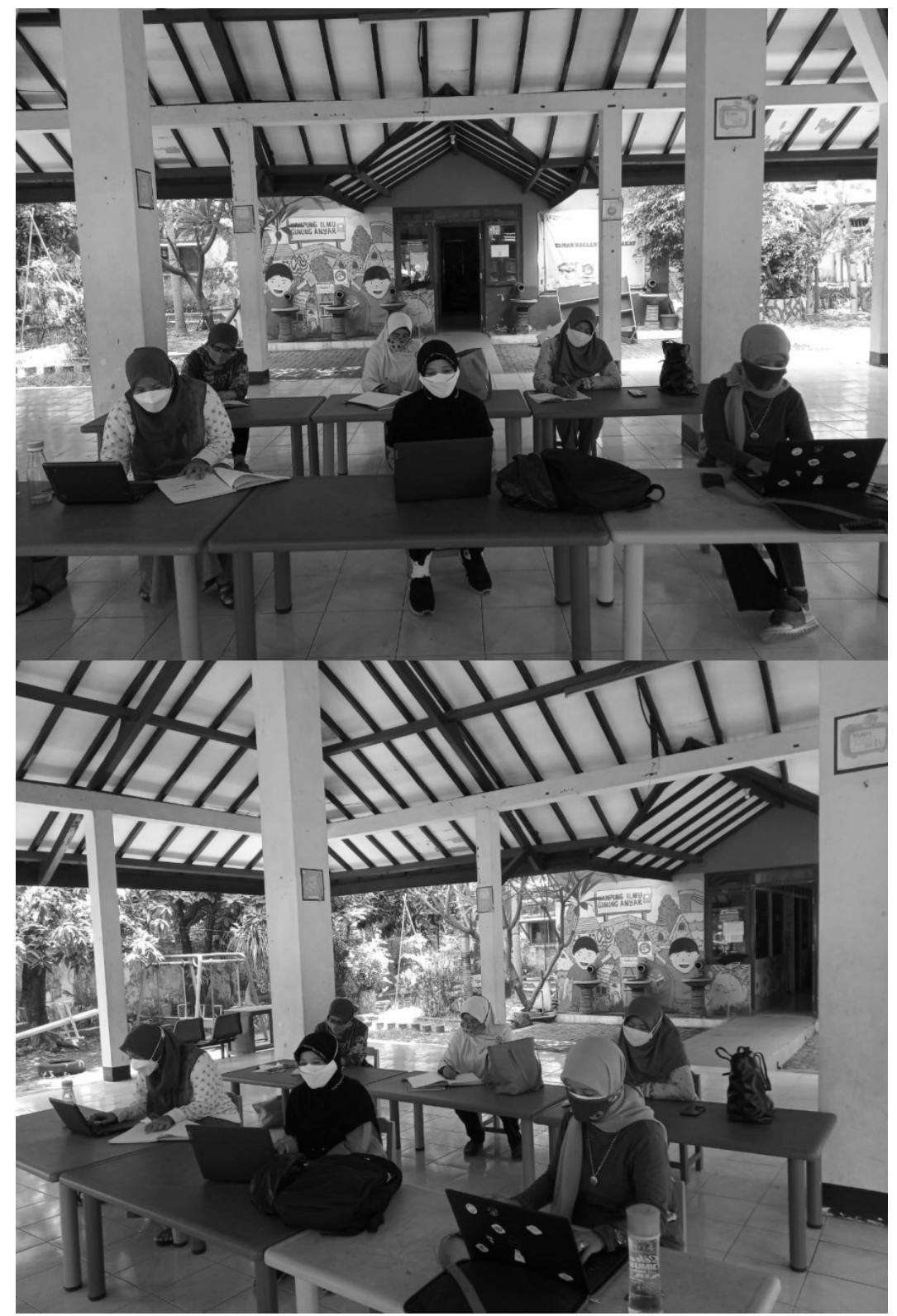

Gambar 1 Pelaksanaan pelatihan Penyusunan RPP dan TIK di PAUD Mawar Surabaya

\section{6 | KESIMPULAN DAN SARAN}

Kegiatan pengabdian kepada masyarakat semacam ini dirasakan sangat besar manfaatnya bagi guru-guru PAUD, karena selain dapat bertukar pikiran mengenai teknik penyusunan RPP, juga guru-guru tersebut dapat memperoleh masukan mengenai alternatif materi yang dapat disisipkan ke dalam RPP. Yang dalam hal ini adalah pengenalan robotika bagi siswa-siswa PAUD. Tentu ide yang diberikan akan sangat baik jika di kemudian hari ditindaklanjuti dalam bentuk pelatihan mengenai pengenalan robotika kepada siswa-siswa PAUD.

Pada tahun-tahun mendatang kegiatan seperti dapat diduplikasi dan dilanjutkan ke lembaga-lembaga PAUD yang lain yang ada di sekitar ITS Surabaya, mengingat jumlah PAUD di kota Surabaya dan kota-kota lain di Jawa Timur sangat banyak 


\section{7 | UCAPAN TERIMA KASIH}

Kami mengucapkan terima kasih kepada Direktorat Riset dan Pengabdian Masyarakat (DRPM) ITS yang telah mendukung kegiatan abdimas ini. Dan ucapan terima kasih kami sampaikan pula kepada pengurus PAUD Mawar Surabaya yang teleh bersedia membantu dan bekerjasama untuk mensukseskan kegiatan abdimas ini. Besar harapan kami agar kegiatan ini dapat terlaksana kembali di lain waktu.

\section{8 | NOMOR KONTRAK}

Nomor : 1081/PKS/ITS/2020

\section{Referensi}

1. Backer B. The Weekly Curriculum Book: 52 Complete Preschool Themes. Gryphon House, Incorporated; 2003.

2. McKay A. The Ultimate Toddler Activity Guide 2018;.

3. Hobbs JC. Preschool Lesson Plans 2020;.

4. Hariadi V, Lianto J, Saikhu A, Purwananto Y, Amaliah B, Wijaya AY, et al. Pelatihan Pembuatan Konten Multimedia untuk Peningkatan Ketrampilan Teknis Bagi Anak Usia Remaja di Yayasan PA Arief Rahman Hakim Surabaya. SEWAGATI 2021;5(2):100-105.

Cara mengutip artikel ini: Hariadi, V. Buliali, J.L. Saikhu, A. Purwananto, Y. Amaliah, B. Wijaya, A.Y., (2022), Klinik Penyusunan Rencana Program Pembelajaran (RPP) dan Pelatihan TIK bagi Guru Pos PAUD Terpadu (PPT) Mawar di Surabaya, Sewagati: Jurnal Pengabdian Kepada Masyarakat, 6(1):61-68. 